\title{
Comparative Analysis of Hand v/s Machine Milking on Bovine Intramammary Infection
}

\author{
Mamta Singh $^{1}$, Bhagirathi ${ }^{1}$, Reena Mukherjee ${ }^{1}$ and Mukesh Shakya ${ }^{2}$ \\ ${ }^{1}$ Department of Medicine, ICAR-Institute, Izatnagar, Bareilly (U.P.)-243122, India \\ ${ }^{2}$ Division of Parasitology, ICAR-IVRI, Izatnagar, Bareilly (U.P.) - 243122 India
}

*Corresponding author

\begin{tabular}{|c|c|}
\hline & A B S T R A C T \\
\hline $\begin{array}{l}\text { K e y w o r d s } \\
\text { Hand milking, } \\
\text { Machine milking, } \\
\text { Mastitis, Somatic } \\
\text { cell count, } \\
\text { Staphylococcus } \\
\text { aureus }\end{array}$ & \multirow{3}{*}{$\begin{array}{l}\text { Mechanization has significantly altered the working conditions of humans and } \\
\text { livestock in dairy industries over the past hundred years. Machine milking is a } \\
\text { common practice from past decades in many organised dairy farms in most of } \\
\text { milk producing country. The production of good quality and hygienic milk are } \\
\text { essential to assess the impact of manual and machine milking method on udder } \\
\text { health. California mastitis test (CMT) and Somatic cell count (SCC) widely used } \\
\text { to predict the mammary health status of quarters (cows) and for the suitability of } \\
\text { milk for human consumption. The objective of this study was to investigate the } \\
\text { relationship of milk somatic cell counts, and mastitis causing Staphylococcus } \\
\text { aureus with regard to the milking practices followed in organized farms. }\end{array}$} \\
\hline Article Info & \\
\hline $\begin{array}{l}\text { Accepted: } \\
\text { 15 September } 2019 \\
\text { Available Online: } \\
10 \text { October } 2019\end{array}$ & \\
\hline
\end{tabular}

\section{Introduction}

According to the present circumstances mastitis has symbolized itself as a most challenging disease in high yielding dairy animals in India next solely to FMD (Foot and Mouth Disease) (Varshney and Mukherjee, 2002). However as per many reports of its occurrence in dairy animals, it places itself at first position with its prevalence reported in more than $90 \%$ of high yielding cows (Reshi, 2015). Annual misfortunes in the dairy business due to mastitis have been around 2 billion dollars in the USA and 7156.53 crores in India (NAAS, 2013). In present scenario clean milk production is very challenging task in most of recognised milk producing countries. It is well known that bacterial, environmental or management, and cow factors may change the susceptibility to mastitis. Many microbial species such as Escherichia coli, Klebsiella pneumoniae, Streptococcus agalactiae and Staphylococcus aureus, Streptococcus uberis, Streptococcus dysgalactiae subsp. dysgalactiae or Staphylococcus chromogenes, are common bacterial causes of bovine mastitis (Zadoks et al., 2011) among which Staphylococcus 
aureus is the most widely recognized causative organism of bovine mastitis ( $\mathrm{Li}$ et al., 2017). The management and environment likely favour the factors involves in causing mastitis; housing (Osteras and Lund, 1988), nutrition (Smith et al., 1984; Barkema et al., 1999), milk production, milking procedures (Schukken, 1990), and dry cow treatment (Berry and Hillerton, 2002) have been found to be associated with Intramammary infections.

Normal milk does contain cells, and the concentration of these cells is almost always less than 100,000 cells $/ \mathrm{ml}$ in milk from uninfected/uninflamed mammary quarters (Barbano, 1999; Dohoo and Meek, 1982; Hamann, 1996; Harmon, 1994; Hillerton, 1999). This is based on twice-daily milking at regular intervals. A cell count of 200,000 cells/ml or greater is a clear indication that an inflammatory response has been elicited (subclinical mastitis), the quarter is likely to be infected, and the milk has reduced manufacturing properties such as reduced shelf life of fluid milk, and reduced yield and quality of cheese (Barbano, 1999; Dohoo, and Meek, 1982). Based on the likelihood of infection and altered manufacturing properties, milk from a mammary quarter with a SCC equal to or greater than 200,000 cells $/ \mathrm{ml}$, with or without clinical signs, is abnormal milk (National mastitis council, 2011).

Monitoring udder health performance is not feasible without reliable and affordable diagnostic methods (Zadoks and Schukken, 2006). The most often used diagnostic methods are CMT, SCC and bacteriological culturing of milk. Currently, methods such as measurement of N-acetyl- $\beta$-Dglucosaminidase (NAGase), lactate dehydrogenase activity (LDH), electric conductivity (EC) on milk, are used less frequently.
Milking is one of the main and final operations that determine profitability of a dairy farm. However, farmers are faced with several challenges that include low productivity, poor hygiene and routines for manual milking. The type of milking, whether by machine or by hand, can affect the incidence of intramammary infections. Hand milking exposes dairy animals to injury, disease transmission hazards and incomplete emptying udder that complicate the cow's health as well as subsequent milk yield (Dzidic, 2004; Christine, 2018). Hand milking is also slow, very tiresome and unhygienic. These challenges can be mitigated by investing in machine milking (Shem et al., 2001). Therefore, many organized dairy farms have embraced machine milking to overcome these difficulties. The aim of this research is to determine the effect of two distinct milking methods (hand vs. machine milking) on somatic-cell-count and microorganisms in milk.

\section{Materials and Methods}

\section{Place of study}

Present Study was conducted in dairy cows specifically the Vrindavani crossbred cattle in an organized dairy farm in Bareilly (U.P.). A total 395 useful udder quarters of 100 lactating Vrindavani cows were screened randomly. Out of 100 cows, 50 are from the group in which hand milking is practiced and rest 50 are from the group in which machine milking is practiced.

\section{California mastitis test}

California mastitis test California mastitis test (CMT) was done on the spot of collection for milk samples. Milk samples were examined for noticeable changes and screened by the CMT according to Quinn et al., (1999) prior to sample collection for bacteriological 
examination. A squirt of milk sample was placed on the CMT paddle in each of the cups from every quarter of the udder, and an equal amount of $3 \%$ CMT reagent was added to each cup and mixed well. Reactions were graded as 0 and Trace for negative, $+1,+2$ and +3 for positive.

\section{Collection of milk sample}

Milk samples were collected according to the procedures recommended by National Mastitis Council (NMC, 1990). The milk sample from affected quarters from each cow was collected after proper disinfection of hand and teat surface with $70 \%$ ethyl alcohol. The first 3-4 streams of milk were discarded. The collecting vial was held as near horizontal as possible and by turning the teat to a near horizontal position, approximately $10 \mathrm{ml}$ of milk was collected aseptically in a sterilized glass test tube. After collection, samples required for the further study were placed in icebox and processed in the same day.

\section{Somatic cell count (SCC)}

The SCC in milk was performed according to Schalm et al., (1971) method with appropriate modification. The milk samples were thoroughly mixed by shaking the vials and $10 \mu \mathrm{l}$ of milk was taken over a grease-free clean glass micro slide on the predawn area of one sq $\mathrm{cm}$, which was smeared uniformly with a fine sterile rod. The smear was dried and examined after staining them with modified Newman's Lampert stain. Cell counting in 10 different fields was carried out under oil immersion lens (100X) and counting was repeated thrice per smear to assess average number of somatic cell in 30 fields. The total number of cell in the milk was estimated by multiplying total number of cells in 10 fields to the working factor of microscope and expressed per ml of milk sample.

\section{Bacteriological examination of milk sample}

Microbiological analysis was performed according to adapted National Mastitis Council methodology (Oliver et al., 2004), with the following ' Bacterial Identification Protocol' provided by Kloos and Schleifer (1975) for the identification of Pathogenic Staphylococcus aureus. The identification of causative organism in collected milk samples were carried out by inoculating $10 \mu \mathrm{l}$ of milk, which spread over 5\% bovine blood agar plates. The isolated organism from milk samples were identified initially on the basis of colony morphology, zone of hemolysis and smell on 5\% blood agar as per Cruickshank (1962).

\section{Culturing methods}

Culture grown in $5 \%$ bovine blood agar was further grown on Mannitol Salt Agar, Bairds' Parker agar and MeReSa agar plates. The suspected colonies from 24 to $48 \mathrm{hrs}$ old culture grown in $5 \%$ bovine blood agar were further grown on Mannitol Salt Agar .Yellowish coloration of the media due to lactose fermentation with bacterial colonies indicating coagulase positive Staphylococci which can be further confirmed by coagulase test. Coagulase positive $S$. aureus was isolated using technique given by Baird Parker, (1962). Enriched samples were streaked on Baird Parker Agar (BP agar) and the plates were incubated at $37^{\circ} \mathrm{C}$ for $24-48$ hours. The appearance of jet black colonies surrounded by a halo was presumably considered to be $S$. aureus.

\section{Molecular characterization of S. aureus \\ Isolation of genomic DNA from bacterial cultures}

Single colony of bacteria from nutrient agar was inoculated in $2 \mathrm{ml}$ Luria Bertini broth 
aseptically and kept in shaker incubator at $37^{\square}$ overnight. $1 \mathrm{ml}$ of bacterial culture suspension was placed into a $1.5 \mathrm{ml}$ micro centrifuge tube, and centrifuge for $5 \mathrm{~min}$ at 5000 x g $(7500$ rpm. Supernatant was discarded, bacterial pellet was suspended in $180 \mu \mathrm{l}$ of the $20 \mathrm{mg} / \mathrm{ml}$ Lysozyme solution and incubated for $30 \mathrm{~min}$ at $37 \mathrm{C}$. Calculate the volume of the pellet or concentrate and add Buffer ATL (supplied in the QIAamp DNA Mini Kit) to a total volume of $180 \mu \mathrm{l}$ ). Add $20 \mu \mathrm{l}$ proteinase $\mathrm{K}$, mix by vortexing, and incubate at $56^{\circ} \mathrm{C}$ until the tissue is completely lysed. Vortex occasionally during incubation to disperse the sample, or place in a shaking water bath or on a rocking platform. Add $200 \mu 1$ Buffer AL to the sample, mix for $15 \mathrm{~s}$ with pulse-vortexing, and incubate at $70^{\circ} \mathrm{C}$ for $10 \mathrm{~min}$. Add $200 \mu \mathrm{l}$ ethanol (96-100\%) to the sample, and mix by pulse-vortexing for $15 \mathrm{~s}$. Suspension from the micro centrifuge tube was carefully transferred to the QIAamp Mini spin column (in a $2 \mathrm{ml}$ collection tube) without wetting the rim and centrifuge at 6000 $\mathrm{x} g(8000 \mathrm{rpm})$ for $1 \mathrm{~min}$. Then the QIAamp Mini spin column was placed in a clean $2 \mathrm{ml}$ collection tube and discard the tube containing the filtrate. Carefully open the QIAamp Mini spin column and add 500 $\mu$ l Buffer AW1 without wetting the rim. Then close the cap, and centrifuge at $6000 \times \mathrm{g}(8000 \mathrm{rpm})$ for 1 min. Place the QIAamp Mini spin column in a clean $2 \mathrm{ml}$ collection tube (provided), and discard the collection tube containing the filtrate. Then carefully open the QIAamp Mini spin column and add 500 $\mu$ Buffer AW2 without wetting the rim. Close the cap and centrifuge at full speed $(20,000 \times \mathrm{g} ; 14,000$ rpm) for $3 \mathrm{~min}$. Place the QIAamp Mini spin column in a new $2 \mathrm{ml}$ collection tube and discard the old collection tube with the filtrate. Centrifuge at full speed for $1 \mathrm{~min}$. Place the QIAamp Mini spin column in a clean $1.5 \mathrm{ml}$ microcentrifuge tube, and discard the collection tube containing the filtrate. Carefully open the QIAamp Mini spin column and add $200 \mu \mathrm{l}$ Buffer AE or distilled water. Incubate at room temperature for $1 \mathrm{~min}$, and then centrifuge at $6000 \mathrm{x} \mathrm{g}(8000 \mathrm{rpm})$ for 1 min. The filtrate containing DNA was collected, labelled, sealed and stored at $20 \square \mathrm{C}$ for future use.

\section{Amplification of staphylococcal $16 \quad \mathrm{~S}$ ribosomal gene (16 S rRNA) and mecA gene}

The following Published primers were used for the amplification of 16S rRNA gene (Lovseth et al., 2004) and mecA gene (Kamal et al., 2013). PCR reaction was carried out in thin wall PCR tubes in $25 \mu 1$ reaction volume. Genomic DNA (70ng) was used as template for amplification of $16 \mathrm{~S}$ rRNA gene and mecA gene. The PCR mixture consisted of $2 \mu 1$ of forward and reverse primers, $0.5 \mu 1$ of each dNTPs and $0.3 \mu 1$ of Taq DNA polymerase with 10x Taq DNA polymerase buffer. The volume of the reaction was made upto $25 \mu 1$ with nuclear free water.

The cycling conditions used for amplification of the genes were as follows:

\begin{tabular}{|c|c|}
\hline 16S rRNA gene & mecA gene \\
\hline Initial denaturation $95^{\circ} \mathrm{C}$ for $5 \mathrm{~min}$. & Initial denaturation $95^{\circ} \mathrm{C}$ for $5 \mathrm{~min}$. \\
\hline Denaturation $95^{\circ} \mathrm{C}$ for $1 \mathrm{~min}$. & Denaturation $95^{\circ} \mathrm{C}$ for $30 \mathrm{sec}$. \\
\hline Primer annealing $64^{\circ} \mathrm{C}$ for $1 \mathrm{~min} 35$ cycles. & Primer annealing $58^{\circ} \mathrm{C}$ for 30 sec. 35 cycles. \\
\hline Primer elongation $72^{\circ} \mathrm{C}$ for $1 \mathrm{~min}$. & Primer elongation $72^{\circ} \mathrm{C}$ for $30 \mathrm{sec}$. \\
\hline Step 5: Final extension $72^{\circ} \mathrm{C}$ for $10 \mathrm{~min}$. & Step 5: Final extension $72^{\circ} \mathrm{C}$ for $5 \mathrm{~min}$. \\
\hline
\end{tabular}


The PCR amplified products were resolved on $2 \%$ agarose gel in $1 \mathrm{X}$ Tris Borate EDTA (TBE) buffer. The agarose gel stained with ethedium bromide was documented under UV light in a gel documentation system (Molecular Imager ${ }^{\circledR}$ Gel Doc ${ }^{\mathrm{TM}} \mathrm{XR}+$ System, BIO Rad, USA).

\section{Statistical analysis}

Descriptive statistics were used for all the variables. Chi-square (x2) was used for assessing the statistical associations of various factors with mastitis.

\section{Results and Discussion}

A total 395 useful udder quarters of 100 lactating cows from organised herd were screened for intramammary infection on the basis of CMT. A total of $7.59 \%$ quarter samples were detected CMT positive, of which $3.03 \%$ samples were from machine milked cows and $4.55 \%$ from hand milked cows. No significant difference was observed between hand and machine milking methods in chi squire test with respect to CMT (Table 1).

The difference, in SCC between the two groups was not significant, most probably due to the great variance of the values. During the study period, $3 \%$ and $1.5 \%$ of hand and machine milking samples, respectively, contained more than 200,000 somatic cells $\mathrm{ml}-1$. The milk samples which had between 1 , 00000 to 200,001 somatic cells $\mathrm{ml}^{-1}$ were $3.75 \%$ and $2.5 \%$, respectively (Table 2 ). SCC in the group of machine milked cows was not found significant as compared to that of the other group. However, Kalyan et al., (2011) reported that the introduction of machine milking, there is an increase in milk SCC which may increase the chance of mammary infection. Some of researchers observed difference in SCC was not significant $(\mathrm{P}>$
0.05), regardless of the different milking methods (Zeng and Escobar, 1996). Sheldrake and co-workers ( 198 1) reported the lowest average $4.4 \times 10^{5} \mathrm{SCC} \mathrm{ml}^{-1}$ in a herd milked by hand and highest average $1.7 \times 10^{6}$ $\mathrm{SCC} \mathrm{ml} \mathrm{l}^{-1}$ in another herd milked by machine. But Dang and Anand (2007) found that average values of SCC were higher $(\mathrm{P}<0.01)$ in hand milked animals than machine milked cows. There was a tendency of higher SCC in the milk of cows that were milked by hand.

Our finding revealed that, there was no significant impact of hand and machine milking method to cause Staphylococcus mastitis in bovine and the findings were similar as observed by Zeng and Escobar (1996). The results were suggested that if milking practice done by trained milkers with proper hygiene than risk factor to spread mastitis causing pathogen by different method could be avoided. Some early reports (Burkey and Sanders, 1949) indicated a higher incidence of mastitis in machine-milked animals than in animals milked by hand. Spencer (1998) noted that the milking machine could influence new intra mammary infection (IMI) by serving as a fomite, allowing cross-infections within cows, damaging teat sphincters or creating teat impacts, he was one of the first to point out that the milking machine is rarely a direct cause of new IMI. The mastitis situation caused by S. aureus, C. bovis, S. agalactiae and coagulase negative staphylococci could be improved by improving milking procedures and hygiene (Haltia et al., 2006). Another hand according to some reports, Therefore the risk of contamination is usually considered higher during manual milking than in mechanic milking (De Luca, 2004; Salimei, 2016). The milkers' hands can be a major factor in the spread of udder infections, tend to reverse this situation, providing machine milking is done properly. 
Table.1 CMT score wise milk samples

\begin{tabular}{|l|l|l|l|l|}
\hline S.No. & CMT Grade & $\begin{array}{l}\text { Hand milked } \\
\text { sample }(\mathbf{n = 1 9 6 )}\end{array}$ & $\begin{array}{l}\text { Machine milked } \\
\text { sample (n=199) }\end{array}$ & $\begin{array}{l}\text { Chi square } \\
\text { value }\end{array}$ \\
\cline { 1 - 2 } & Trace & $2.04 \%(4)$ & $2.01 \%(4)$ & $3.822(\mathrm{a})^{*}$ \\
\hline $\mathbf{2}$ & week positive & $2.55 \%(5)$ & $3.01 \%(6)$ & \\
\hline $\mathbf{3}$ & Distinct positive & $3.57 \%(7)$ & $1.00 \%(2)$ & \\
\hline $\mathbf{4}$ & Strong positive & $1.02 \%(0)$ & 0 & \\
\hline
\end{tabular}

*non significance $(\mathrm{p}>0.05)$

Table. 2 Somatic cell count (SCC) of milk samples

\begin{tabular}{|l|l|l|l|l|}
\hline SN & $\begin{array}{l}\text { Somatic cells count/ml } \\
\text { milk }\end{array}$ & $\begin{array}{l}\text { Hand milked } \\
\text { sample (n=18) }\end{array}$ & $\begin{array}{l}\text { Machine milked } \\
\text { sample (n=12) }\end{array}$ & $\begin{array}{l}\text { Chi square } \\
\text { value }\end{array}$ \\
\hline $\mathbf{1}$ & $<1,00,000$ & $27.77 \%(5)$ & $33.33 \%(4)$ & $0.255(\mathrm{a})^{*}$ \\
\hline $\mathbf{2}$ & $1,00,000-200,000$ & $38.88 \%(7)$ & $41.66 \%(5)$ & \\
\hline $\mathbf{3}$ & $>200,000$ & $33.33 \%(6)$ & $25 \%(3)$ & \\
\hline
\end{tabular}

Fig.1 Agarose gel showing amplified 16S rRNA gene from mastitis milk samples

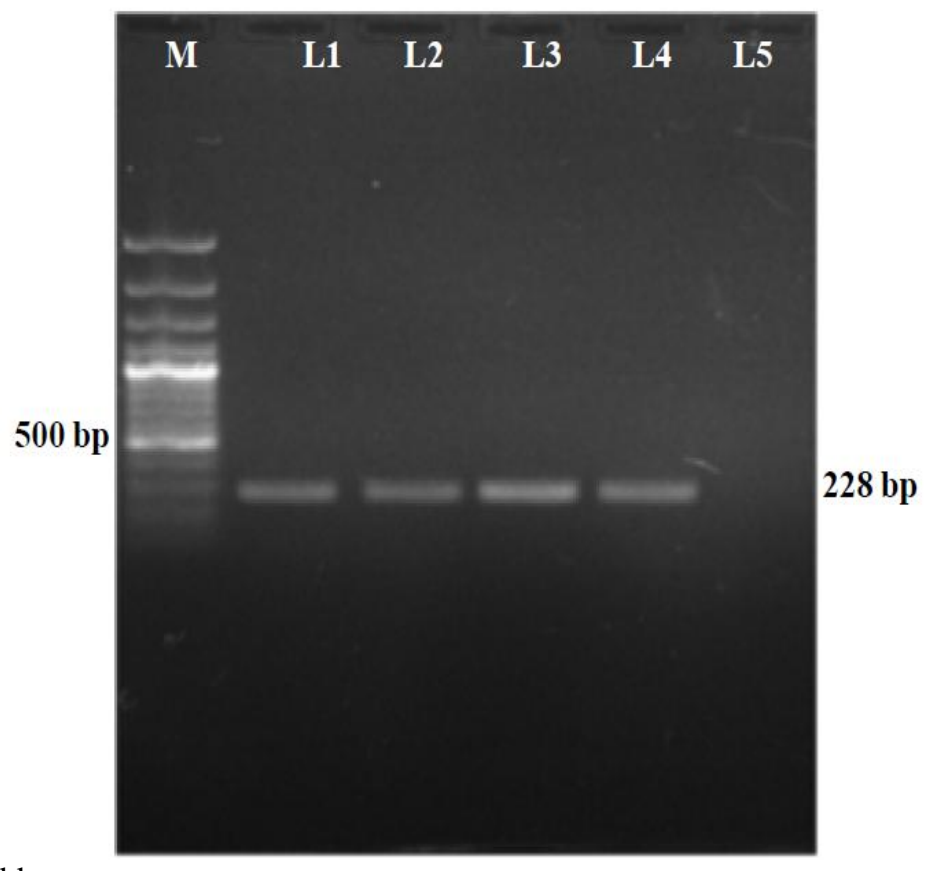

Lane M: 100 bp DNA ladder

Lane 1-4: PCR amplification of 16S rRNA gene in mastitis milk samples affected with Staphylococcus infection. Lane 5: No template control (NTC). 
Fig.2 Agarose gel showing amplified mecA gene from mastitis milk samples

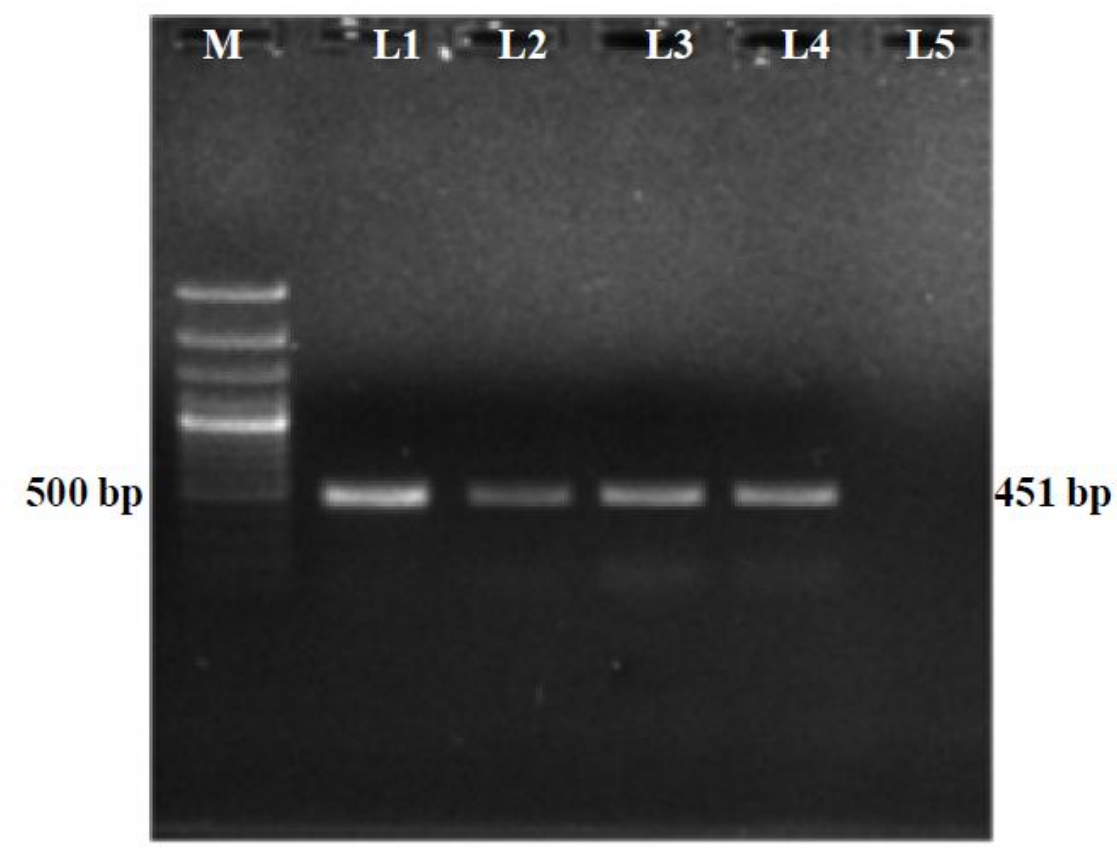

Lane M: 100 bp DNA ladder

Lane 1-4: PCR amplification of mecA gene in mastitis milk samples affected with Staphylococcus aureus infection. Lane 5: No template control (NTC)

Based on PCR amplification of $16 \mathrm{~S}$ rRNA (228bp) and mecA (451bp) gene in mastitis milk samples, $3.06 \%$ samples were found positive for Staphylococcus infection out of which $1.53 \%$ samples were also detected positive for Methicillin- resistance Staphylococcus aureus in hand milked animals. However, in machine milked animals $1.50 \%$ samples were found positive for Staphylococcus infection and all samples were found negative for Methicillin resistance Staphylococcus aureus (Fig. 1 and 2). Amplification of $16 \mathrm{~S} r R N A$ gene sequences is the most commonly used method for identifying and classifying bacteria, including staphylococci (Petti et al., 2005; Mohammad et al., 2007). Bacterial 16S rRNA genes generally contain nine "hypervariable regions" that demonstrate considerable sequence diversity among different bacterial species and can be used for species identification (Van de Peer et al.1996).
PCR based molecular methods are considered to be the gold standard for MRSA detection (Brown et al., 2005).MRSA isolates have intrinsic resistance to penicillinase-resistant beta-lactam antibiotics like cloxacillin, oxacillin. This resistance is based on "mecA" gene encoding penicillin-binding protein $2 \mathrm{a}$ (PBP2a), an altered form of PBP that has low affinity for binding $\beta$-lactam antibiotics (Kaszanyitzky et al., 2001).

In conclusion, the milking methods direct or indirect offer multiple opportunities for bacteria to be cause intramammary infection in cows. From last decade it is a controversy which method is better in respect to minimize the infection in quarters. Introducing of machine milking instead of hand milking can improve the hygienic quality of milk and increased the work efficiency on farms, but no difference in causing to bovine mastitis. 
The PCR based methods for detection of Staphylococcus aureus mastitis is gold standard if possible.

\section{Acknowledgements}

The authors are grateful to the ICAR- Indian Veterinary Research institute, Bareilly (U.P.), for its throughout support.

\section{Funding}

The authors received funding from the ICARIndian Veterinary Research institute, Bareilly, (U.P.).

\section{Conflict of interest}

The authors declare that they have no conflict of interest.

\section{References}

Barbano, D.M. 1999. Influence of mastitis on cheese manufacturing. In: Practical Guide for control of cheese yield, International Dairy Federation, Brussels, Belgium. pp. 19-27.

Barkema, H.W., Schkken, Y., Lam, T.J.G.M., Beiboer, M.L., Benedictus, G., Brand, A. 1999. Management Practices Associated with the Incidence Rate of Clinical Mastitis. Journal of Dairy Science. 82: 1643-1654.

Berry, E.A. and Hillerton, J.E. 2002. The Effect of Selective Dry Cow Treatment on New Intramammary Infections. Journal of Dairy Science. 85:112-121.

Brown, D.F.J. and Walpole, E. 2001. Evaluation of the Mastalex latex agglutination test for methicillin resistance in Staphylococcus aureus grown on different screening media. Journal of Antimicrobial Chemotherapy. 47:187-9.

Burkey, L. A., and Sanders, G. P. 1949.The
Significance of Machine Milking in the Etiology and Spread of Bovine Mastitis: A Review. USDA, ARS, BAI, BDIMInf-77.

Christine, O. 2018. Trends in Hand Milking and Machine Milking in Kenya. Journal of Engineering and Applied Sciences. 13: 5655-5660.

Cruickshank, R. 1962. Mackie and Mc Cartney's Handbook of Bacteriology, 10th Edition, $\mathrm{E}$ and S. Livingstone limited, Edinburgh, London. 431 p.

Dang, A. K. and Anand, S. K. 2007. Effect of milking systems on the milk somatic cell counts and composition. Livestock Research for Rural Development.19: 19.

De Luca, G., 2004. L'allevamento Della capra. Edagricole, Bologna

De, K., Mukherjee, J., Dang, A. K. and Prasad, S. 2011. Effect of different physiological stages and managemental practices on milk somatic cell counts of Murrah buffaloes. Buffalo Bulletin. 30(1): 72-74.

Dohoo, I. R. and Meek, A.H. 1982. Somatic cell counts in bovine milk. Canadian Veterinary Journal. 23: 119-125.

Dzidic, A. 2004. Studies on milk ejection and milk removal during machine milking in different species. Technical University of Munich, Munich, Germany.33p

Haltia, L., Honkanen-Buzalski, T., Spiridonova, I., Olkonen, A., and Myllys, V. 2006. A study of bovine mastitis, milking procedures and management practices on 25 Estonian dairy herds. Acta veterinaria Scandinavica. 48(1): 22.

Hamann, J. 1996. Somatic cells: factors of influence and practical measures to keep a physiological level. Mastitis Newsletter, Newsletters of the IDF No. 144, pp. 9-11.

Harmon, R. J. 1994. Physiology of mastitis 
and factors affecting somatic cell counts. Journal of Dairy Science. 77: 2103-2112.

Hillerton, J.E. and Semmens, J.E. 1999.Comparison of treatment of mastitis by oxytocin or antibiotics following detection according to changes in milk electrical conductivity prior to visible signs. Journal of Dairy Science. 82(1): 93-98.

Kamal, M.R., Mohamed, A.B.and Salah, F.A.2013. MRSA detection in raw milk, some dairy products and hands of dairy workers in Egypt, amini-survey. Food Control. 33(1): 49-53.

Kaszanyitzky, E..J., Egyed, Z., Janosi, S., Keseru, J., Gal, Z., Szabo, I., Veres, Z., Somogyi, P. 2004. Staphylococci isolated from animals and food with phenotypically reduced susceptibility to $\beta$-lactamase $\quad$ resistant $\quad \beta$-lactam antibiotics. Acta Veterinaria Hungarica. 52 (1): 7-17.

Kloos, W.E. and Schleifer, K.H. 1975. Isolation and characterization of staphylococci from human skin. II.Descriptions of four new species: Staphylococcus warneri,

Staphylococcus captitis, Staphylococcus hominis, and Staphylococcus simulans. International Journal of Systematic Bacteriology. 25(1): 62-79.

Li, T., Lu, H., Wang, X., Gao, Q., Dai, Y., Shang, J., and Li, M. 2017. Molecular Characteristics of Staphylococcus aureus Causing Bovine Mastitis between 2014 and 2015. Frontiers in Cellular and Infection Microbioogy. $7: 127$

Lovseth, A., Loncarevic, S. and Berdal, K. G. 2004. Modified Multiplex PCR Method for detection of Pyrogenic Exotoxin Genes in Staphylococcal Isolates. Journal of clinical Microbiology. 42(8):3869- 3872

Mohamed, A., Simeon, E., and Yemesrach,
A. 2004. Dairy development in Ethiopia. International Food Policy Research Institute, EPTD Discussion Paper No. 123. Washington, DC, U.S.A. NAAS. 2013. Mastitis Management in Dairy Animals. Policy Paper No. 61, National Academy of Agricultural Sciences, New Delhi, India.p1-12.

National Mastitis Council (NMC).1990. Microbiological procedures for the diagnosis of bovine udder infection, 3 ed. NMC, Arlington. pp: 1-15.

National Mastitis Council. 2001. Guidelines on normal and abnormal raw milk based on somatic cell counts and signs of clinical mastitis. Accessed Oct. 31, 2015.

Oliver, S.P., Gillespie, B.E., Headrick, S.J., Moorehead, H., Lunn, P., Dowlen, H.H., Johnson, D.L., Lamar, K.C., Chester, S.T., and Moseley, W.M.2004. Efficacy of extended ceftiofur intramammary therapy for treatment of subclinical mastitis in lactating dairy cows. Journal of Dairy Science. 87: 2393-2400.

Osteras, O. and Lund, A. 1988. Epidemiological analyses of the associations between bovine udder health and housing. Preventive Veterinary Medicine. 6(2):79-90.

Petti, C. A., Polage, C. R., and Schreckenberger, P. 2005. The Role of $16 \mathrm{~S}$ rRNA Gene Sequencing in Identification of Microorganisms Misidentified by Conventional Methods. Journal of Clinical Microbiology. 43(12): 6123-6125.

Quinn, P.J., Carter, M.E., Markey, B. and Carter, G.R. 1999. Clinical Veterinary Microbiology. Moshy, London, UK. p21-66.

Reshi, A.A., Husain, I., Bhat, S.A., Rehman, M.U., Razak, R., Bilal, S. and Mir M.R. 2015. Bovine mastitis as an evolving disease and its impact on the dairy 
industry. International Journal of Current Research and Review. 7(5): 4855

Salimei, E. 2016. Animals that produce dairy foods: donkey. In: Berryman, R. (Ed.), Reference Module in Food Sciences. Elsevier Ltd., Amsterdam, pp. 1-10.

Schalm, O. W., Carrol, E. J. and Jain, N. C. 1971. Bovine Mastitis. Lea and Febiger. Philadelphia, pp. 128-129.

Schukken Y.H., Grommers F.J., Vande Geer D., Erb H.N. and Brand A. 1990. Risk factors for clinical mastitis in herds with a low bulk milk somatic cell count. I. Data and risk factors for all cases. Journal of Dairy Research. 73: 34633471.

Shem, M., Malole, J., Machangu, R., Kurwijila, L. and Fujihara, T. 2001.Incidence and Causes of SubClinical Mastitis in Dairy Cows on Smallholder and Large Scale Farms in Tropical Areas of Tanzania. AsianAustralian Journal Animal Science. 14(3): 372-377.

Smith, K. L., Harrison, J. H., Hancock, D. D., Todhunter, D. A., and Conrad, H. R. 1984. Effect of Vitamin E and Selenium Supplementation on Incidence of Clinical Mastitis and Duration of Clinical Symptoms. Journal of Dairy
Science. 67(6):1293-1300.

Van de Peer, Y., Van der Auwera, G. and De Wachter, R. 1996. The evolution of stramenopiles and alveolates as derived by "substitution rate calibration" of small ribosomal subunit RNA. Journal of Molecular Evolution. 42(2): 201210.

Varshney, J.P. and Mukherjee, R. 2002. Recent advances in management of bovine mastitis. Intas Polivet. 3(1): 6265.

Zadoks, R. N., and Schukken, Y. H. 2006. Use of Molecular Epidemiology in Veterinary Practice. Veterinary Clinics of North America: Food Animal Practice. 22(1): 229-261.

Zadoks, R.N., Middleton, J.R. and McDougall, S. Katholm, J. and Schukken, Y.H. 2011. Molecular epidemiology of mastitis pathogens of dairy cattle and comparative relevance to humans. Journal of Mammary Gland Biology Neoplasia. 16: 357-372.

Zeng, S. S., and Escobar, E. N. 1996. Effect of breed and milking method on somatic cell count, standard plate count and composition of goat milk. Small Ruminant Research. 19(2): 169-175.

\section{How to cite this article:}

Mamta Singh, Bhagirathi, Reena Mukherjee and Mukesh Shakya. 2019. Comparative Analysis of Hand v/s Machine Milking on Bovine Intramammary Infection. Int.J.Curr.Microbiol.App.Sci. 8(10): 1940-1949. doi: https://doi.org/10.20546/ijcmas.2019.810.226 